\title{
Papular mucinosis: A report of two cases
}

\author{
Papüler müsinozis: Iki olgu sunumu
}

\section{Selami Aykut Temiz, ๑ Arzu Ataseven, ๑ İlkay Özer, ๑ Recep Dursun, ๑ Sıddıka Fındık*}

Necmettin Erbakan University Meram Faculty of Medicine, Department of Dermatology; *Department of Pathology, Konya, Turkey

\begin{abstract}
Papular mucinosis (PM) (lichen myxoedematosus) is a unique, chronic idiopathic disease characterized by lichenoid papules or nodules due to dermal mucin deposition and a variable degree of fibrosis. PM is a quite rare disease of unknown etiology, with fewer than one hundred and fifty cases reported. In this paper, we present two cases of PM with no associated monoclonal gammopathy in two male patients aged 75 and 38 years, for its rare occurrence in the literature.

Keywords: Cutaneous mucinosis, papular mucinosis, paraproteinemia, lichen myxoedematosus
\end{abstract}

Öz

Papüler müsinozis (PM) (liken miksödematozis) likenoid papüller ve nodüller, dermal müsin birikimi ve değişken derecedeki fibrozis ile karakterize derinin oldukça nadir, kronik ve idiyopatik bir hastalı̆ıdır. PM etiyolojisi bilinmeyen, literatürde yüz elli olgudan daha az bildirilmiş olan, oldukça nadir görülen bir hastalıktır. Literatürde seyrek görülmesi nedeniyle ek bir hastalıkla ilişkili olmayan iki PM olgumuzu sunmak istedik. Burada, 75 ve 38 yaşında iki erkek PM’li hasta monoklonal gammopati olmaksızın nadir olarak görüldüğünden dolayı sunulmaktadır.

Anahtar Kelimeler: Kutanöz müsinozis, papüler müsinozis, paraproteinemi, liken miksödematozis

\section{Introduction}

Mucinoses are a heterogeneous group of disorders in which abnormal amount of mucin accumulates in the skin, either diffusely or locally ${ }^{1}$. Cutaneous mucinoses may be listed as primary, in which mucin deposition is the major histologic property resulting in clinically characteristic lesions, and secondary, in which mucin represents an associated histologic finding. The classification of cutaneous mucinoses is complicated because the pathogenetic mechanism of mucin accumulation is not fully understood.

\section{Case Reports}

Case 1

The first case was a 75-year-old man. He presented with asymptomatic, flesh-colored papules mainly distributed over his left leg (Figure 1). These papular lesions have raised five months ago. He had type 2 diabetes mellitus and gonarthrosis in his medical history. Laboratory studies and thyroid function tests were normal. The patient had left knee operations eight times due to recurrent prosthetic infection. Histopathological examination revealed hyperkeratosis, atrophic changes, vascular proliferation and widespread mucin accumulation in the papillary dermis (Figure 2). The myxoid appearance in the dermis was found to be mucin accumulation with toluidine blue staining (Figure 3). The final diagnosis was papular mucinosis (PM).

The department of hematology was consulted for investigation of monoclonal gammopathy. The patient's protein electrophoresis and bone marrow biopsy were normal. Monoclonal gammopathy was not detected. Systemic treatment, such as melphalan, thalidomide, interferon

Address for Correspondence/Yazışma Adresi: Selami Aykut Temiz MD, Necmettin Erbakan University Meram Faculty of Medicine,

Department of Dermatology, Konya, Turkey Phone: +90 5358430068 E-mail: aykutmd42@gmail.com

Received/Geliş Tarihi: 08.01.2018 Accepted/Kabul Tarihi: 20.06.2018 ORCID ID: orcid.org/0000-0003-4878-0045

CCopyright 2018 by Turkish Society of Dermatology and Venereology

Turkderm-Turkish Archives of Dermatology and Venereology published by Galenos Yayınevi. 


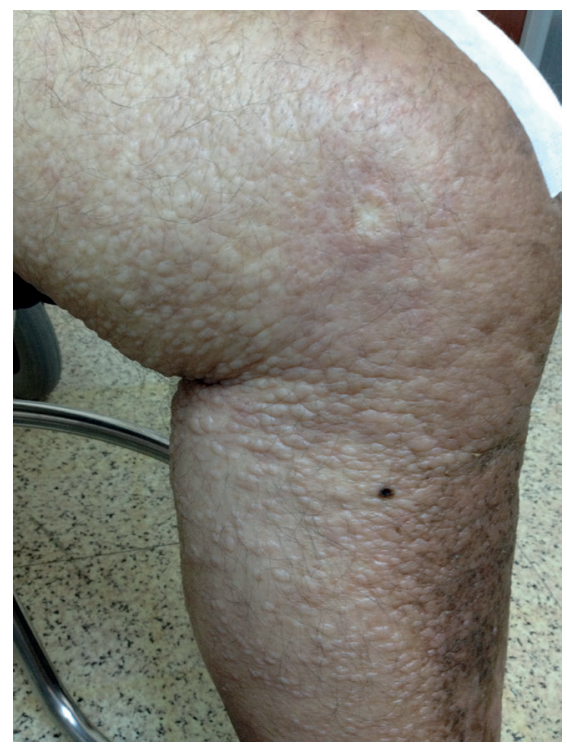

Figure 1. Asymptomatic, flesh-colored papules mainly distributed over the left leg

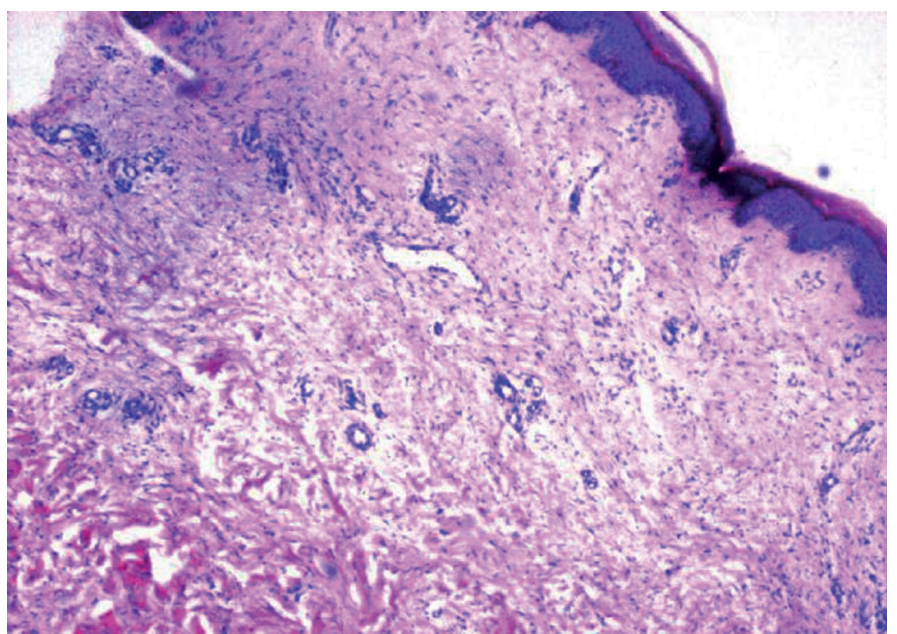

Figure 2. Histopathological examination revealed hyperkeratosis, atrophic changes, vascular proliferation and widespread mucin accumulation in the papillary dermis (hematoxylin and eosin, $x 40$ )

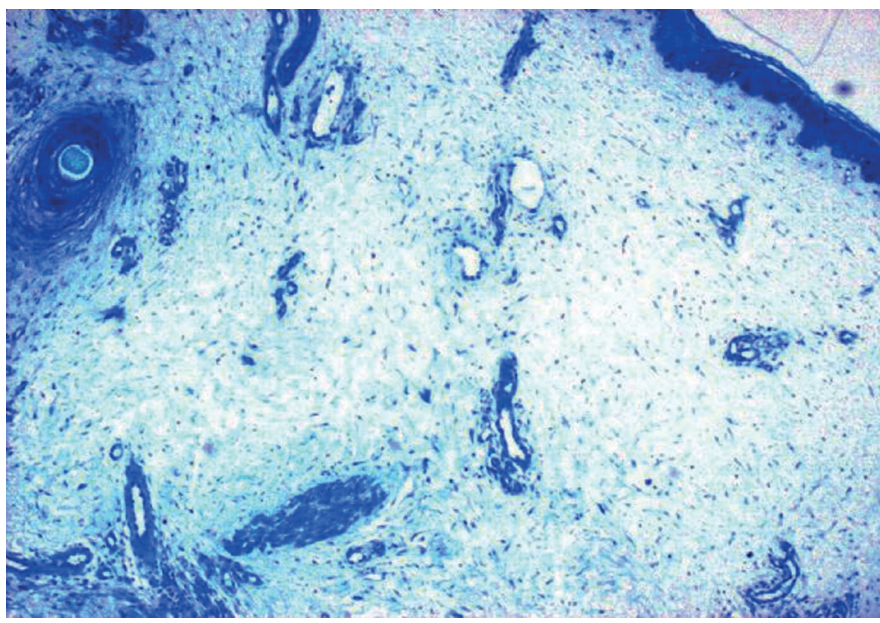

Figure 3. Mucin accumulation with toluidine blue staining (toluidine blue, $x 4$ ) alpha, autologous stem-cell transplantation, cyclophosphamide, plasmapheresis or intravenous immunoglobulin (IVIG) was not planned by hematologists. The radiation oncology department was consulted for radiotherapy. Radiotherapy was not planned because it could increase leg edema and affect prosthetic infected tissue. Narrow band ultraviolet (UV) B therapy was recommended to the patient but he refused treatment because he could not move. $0.1 \%$ retinoic acid and $0.1 \%$ diflucortolone valerate $10 \mathrm{mg}$ were given twice daily. The patient's consent to publication was obtained.

\section{Case 2}

The second case was a 38-year-old man. He presented with itchy, fleshcolored papules mainly distributed over his right back. Dermatologic examination revealed papular and nodular lesions on the back, especially over the right scapular area (Figure 4). His medical and family history was unremarkable. Thyroid function tests were normal. Skin biopsy was performed with the preliminary diagnoses of PM, eruptive collagenoma and lipoid proteinosis on the back of the two lesions. Histopathological examination revealed that starting from just below the epidermis, the upper dermis was myxoid in character and this view was confined to the upper dermis. There were hyperkeratosis, atrophic changes, vascular proliferation and diffuse mucin accumulation in the papillary dermis (Figure 5). The myxoid appearance in the dermis was found to be mucin accumulation with alcian blue staining (Figure 6). The final diagnosis was PM.

Hematology consultation was requested for investigation of paraproteinemia. The patient's protein electrophoresis was normal. Bone marrow biopsy was not needed for diagnosis. Our patient was clinically diagnosed with localized papular mucinous lesions with the presence of lesions, histopathological evidence, and without monoclonal gammopathy and thyroid disease. The patient received $0.1 \%$ betamethasone ointment treatment. Significant regression of lesions was observed after two months of follow-up. The patient's consent to publication was obtained.

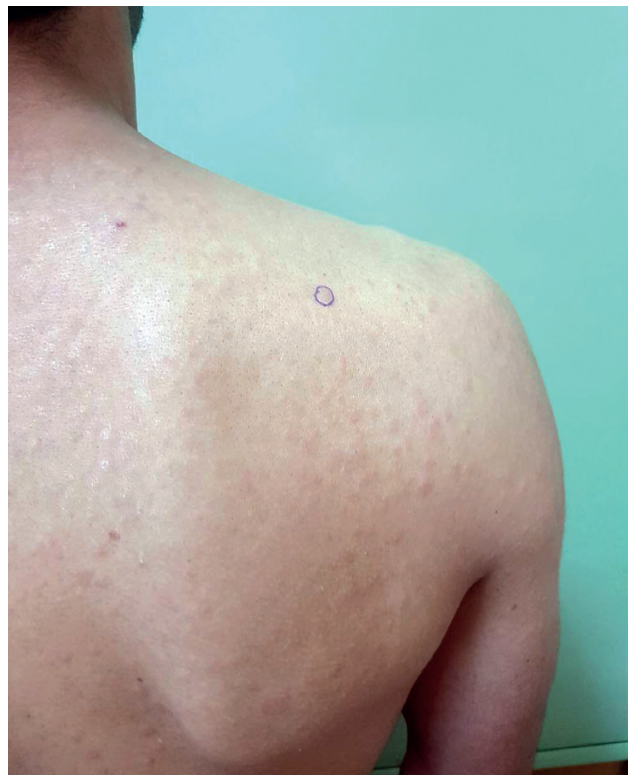

Figure 4. Papular and nodular lesions on the back, especially in the right scapular area 


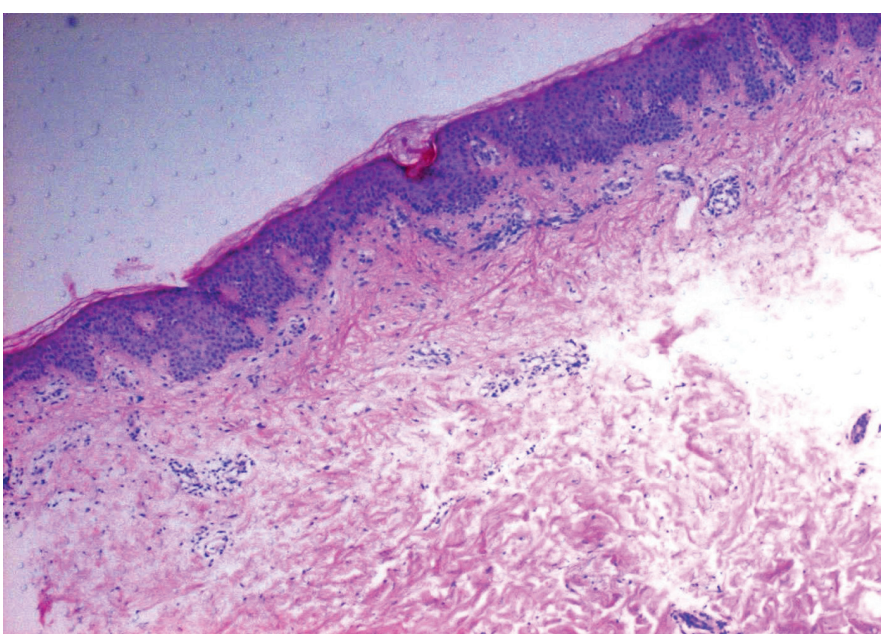

Figure 5. Diffuse mucin accumulation in the papillary dermis (hematoxylin and eosin, $x 40$ )

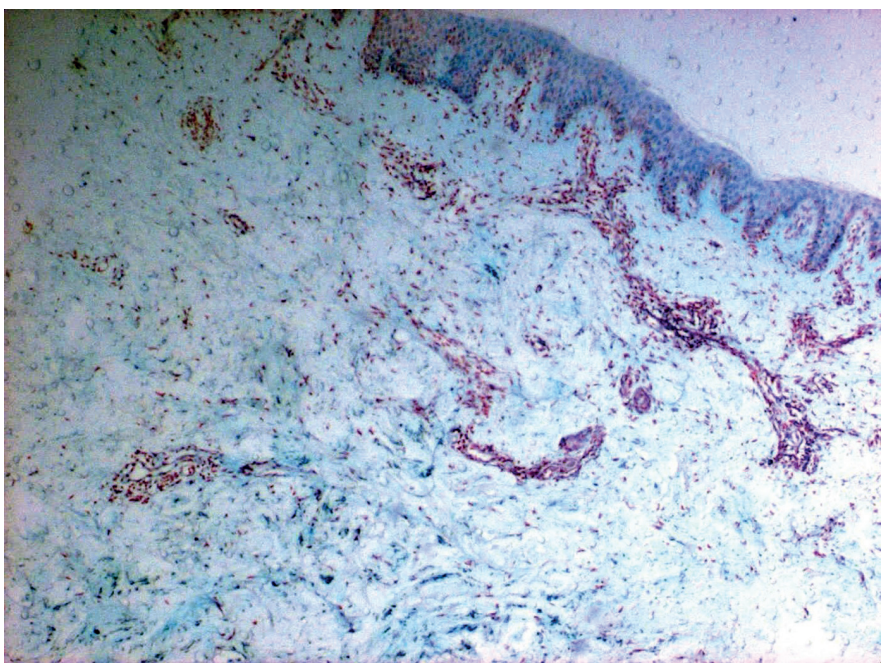

Figure 6. Mucin accumulation with alcian blue staining (alcian blue, x40)

\section{Discussion}

PM (lichen myxoedematosus) is a unique, chronic, idiopathic disease characterized by lichenoid papules, nodules due to dermal mucin deposition and a variable degree of fibrosis². Montgomery and Underwood classified four kinds of PM in 1953: a generalized lichenoid eruption, later named scleromyxedema, a localized or generalized lichenoid plaque form, a discrete papular form and an urticarial plaque form ${ }^{3}$. PM and lichen myxoedematoses have often been used as indiscriminately synonyms in the literature ${ }^{4}$. PM is generally associated with monoclonal gammopathy ${ }^{5}$.

PM is a quite rare disease of unknown etiology with fewer than one hundred and fifty cases reported in the literature ${ }^{4}$. PM contains two clinicopathologic types: a diffused papular and sclerodermoid form (named scleromyxoedema) and a localized papular form ${ }^{6}$. The distinction between these two forms is important because treatment approaches differ. The most important point of differentiation is the extensiveness of skin involvement. Scleromyxoedema differs from other skin mucinoses by four diagnostic findings: generalized papular and sclerodermoid eruption, dermal mucin accumulation with fibroblast reproduction and fibrosis, and monoclonal gammopathy without thyroid disease ${ }^{2}$. In the classification by Rongioletti and Rebora ${ }^{6}$, which has been widely accepted in recent years, cutaneous mucinosis forms have been described as scleromyxoedema (generalized papular), localized, and atypical forms. Systemic mucin deposition may occur with gastrointestinal, pulmonary, renal, cardiac, and neurological involvements ${ }^{7}$. Monoclonal gammopathy and paraproteinemia are detected in the vast majority (83.2\%) of scleromyxoedema cases. $10 \%$ of cases can progress to multiple myeloma.

Diagnostic criteria for localized papular form include papular or nodular eruption, mucin accumulation, fibroblast reproduction at different grades without monoclonal gammopathy and thyroid disease. Lesions show slow progression with no systemic involvement. However, spontaneous recovery is extremely rare. We also accepted our cases as localized papular form. The localized form has five subtypes: discrete PM (DPM), which can appear anywhere on the body; acral persistent PM, which only affects the extensor surfaces of the hands and wrists; self-cure adolescent and adult type PM; infantile PM and, nodular form ${ }^{6}$. Our patients were considered to have the DPM subtype of PM. DPM may be associated with hepatitis $C$ virus (HCV) or human immunodeficiency virus (HIV) infections ${ }^{8}$. We did not detect these diseases in our patients. About 20 cases of DPM have been described that were not associated with HCV or HIV infection?.

Scleroderma (systemic sclerosis), scleredema, eruptive papular xanthoma, lichen amyloidosis, lichen planus and lichenoid drug eruption should be considered in the differential diagnosis of scleromyxedema ${ }^{1}$. In particular, the existence of papules in linear arrays is a useful practical sign. In addition, papules not present in scleroderma are distinctive for scleromyxedema ${ }^{9}$.

The treatment of PM therapy is very challenging because the literature about the treatment is restricted to case reports and series. Melphalan, thalidomide, high-dose dexamethasone, methotrexate, cyclophosphamide, chloroquine, retinoids, chemotherapeutic agents, psoralen plus ultraviolet A (PUVA), interferon alpha, radiotherapy, plasmapheresis, IVIG, and autologous stem-cell transplantation are possible treatment options ${ }^{10}$. The side effects limit the use of these treatments. The first suggested treatment is melphalan therapy (an alkylating agent) ${ }^{11}$. Successful results with IVIG and thalidomide have been reported in the literature ${ }^{12,13}$. Retinoids inhibit mucin secretion by inhibiting fibroblast proliferation ${ }^{14}$. PUVA and electron beam irradiation outcomes should also be discussed ${ }^{15,16}$. The contribution of long-term remission of autologous stem cell transplantation to these cases has also been controversial in recent years ${ }^{17,18}$. Favorable results of steroid treatment have been reported ${ }^{19,20}$. Steroid therapy is thought to target both the production of paraprotein through its immunosuppressive and anti-fibroblast effects ${ }^{21}$. We did not consider systemic treatment in our cases with limited skin involvement. We observed regression of lesions with high-potent topical corticosteroids.

As a result, $\mathrm{PM}$ is rare; it must be considered in the differential diagnosis of patients with skin-colored papular lesions. 


\section{Ethics}

Informed Consent: It was taken.

Peer-review: Externally peer-reviewed.

\section{Authorship Contributions}

Surgical and Medical Practices: S.A.T., A.A., S.F., Concept: S.A.T., A.A., i.Ö., R.D., S.F.,

Design: S.A.T., A.A., I.Ö., Data Collection or Processing: S.A.T., A.A. i.Ö., S.F., Analysis or Interpretation: S.A.T., A.A., I.Ö., R.D., S.F., Literature Search: S.A.T., A.A., I.Ö., R.D., S.F., Writing: S.A.T., A.A.

Conflict of Interest: No conflict of interest was declared by the authors.

Financial Disclosure: The authors declared that this study received no financial support.

\section{References}

1. Popović $D$, Paravina M, Jovanović $D$, et al: Scleromyxedema (Arndt Gottron Syndrome): a Case Report. Serbian Journal of Dermatology and Venereology 2016:8:28-38

2. Allam M, Ghozzi M: Scleromyxedema: a case report and review of the literature. Case Rep Dermatol 2013;5:68-175.

3. Akış HK, Eskioğlu F, Öztürk E: "Diskret" Papüler Müsinoz: Liken Miksödematozun Nadir Bir Subtipi. Turkderm 2011;45:104-6.

4. Mehta V, Balachandran C, Rao R: Arndt Gottron scleromyxedema: successful response to treatment with steroid minipulse and methotrexate. Indian J Dermatol 2009:54:193-5.

5. Rebellato PR, Carbonar MB, Tabuti NI, Rastelli GJ: Case for diagnosis. Lichen myxedematosus. An Bras Dermatol 2016;91:842-3.

6. Rongioletti F, Rebora A: Updated classification of papular mucinosis, lichen myxedematosus, and scleromyxedema. J Am Acad Dermatol 2001;44:273-81.

7. Burns DA, Breathnach SM, Cox N, Griffiths C: Rook's Textbook of Dermatology. 2004

8. Concheiro J, Pérez-Pérez L, Peteiro C, Labandeira J, Toribio J: Discrete papular lichen myxoedematosus: a rare subtype of cutaneous mucinosis. Clin Exp Dermatol 2009;34:608.
9. Finkel LJ, Headington JT: Cutaneous mucinosis and amyloidosis. Dermatology 1992:3:1597-602.

10. Blum M, Wigley FM, Hummers LK: Scleromyxedema: a case series highlighting long-term outcomes of treatment with intravenous immunoglobulin (IVIG). Medicine (Baltimore) 2008:87:10-20.

11. Cokonis Georgakis CD, Falasca G, Georgakis A, Heymann WR: Scleromyxedema. Clin Dermatol 2006;24:493-7.

12. Lopez L, Wierzbicka-Hainaut E, Villers A, Guillet G: Efficacy of intravenous immunoglobulin in Arndt-Gottron scleromyxedema. Ann Dermatol Venereol 2009;136:330-6.

13. Efthimiou P, Blanco M: Intravenous gammaglobulin and thalidomide may be an effective therapeutic combination in refractory scleromyxedema: case report and discussion of the literature. Semin Arthritis Rheum 2008:38:188-94.

14. Serdar ZA, Altunay IK, Yasar SP, Erfan GT, Gunes P: Generalized papular and sclerodermoid eruption: Scleromyxedema. Indian J Dermatol Venereol Leprol 2010;76:592.

15. Brenner M, Herzinger T, Berking C, Plewig G, Degitz K: Phototherapy and photochemotherapy of sclerosing skin diseases. Photodermatol Photoimmunol Photomed 2005;21:157-65.

16. Rampino M, Garibaldi E, Ragona R, Ricardi U: Scleromyxedema: treatment of widespread cutaneous involvement by total skin electron-beam therapy. Int J Dermatol 2007;46:864-7.

17. Ataergin S, Arpaci F, Demiriz M, Ozet A: Transient efficacy of double highdose chemotherapy and autologous peripheral stem cell transplantation immunoglobulin, thalidomide, and bortezomib in the treatment of scleromyxedema. Am J Clin Dermatol 2008;9:271-3.

18. Cheng T, Gnanakumar V, Hegedus C, Stewart DA: Complete and durable remission in a patient with life-threatening scleromyxedema treated with high-dose melphalan and BU with auto-SCT. Bone Marrow Transplant 2008:42:215-7.

19. Horn KB, Horn MA, Swan J, Singhal S, Guitart J: A complete and durable clinical response to high-dose dexamethasone in a patient with scleromyxedema. J Am Acad Dermatol 2004;51(2 Suppl):120-3.

20. Kreuter A, Altmeyer P: High-dose dexamethasone in scleromyxedema: report of 2 additional cases. J Am Acad Dermatol 2005:53:739-40.

21. Lin YC, Wang HC, Shen JL: Scleromyxedema: An experience using treatment with systemic corticosteroid and review of the published work. J Dermatol 2006;33:207-10 